\title{
2011 APSA Teaching and Learning Conference Track Summaries
}

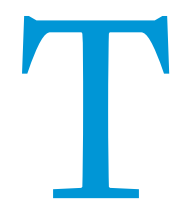

he eighth annual APSA Teaching and Learning Conference (TLC) was held in Albuquerque, New Mexico, February 11-13, 2011, with 226 attendees onsite. The theme for the meeting was "Making Sense of Politics and Political Science." Using the workinggroup model, the TLC track format encourages in-depth discussion and debate on research dealing with the scholarship of teaching and learning.

In addition to the 13 working groups, there were 20 workshops on various topics. The 2011 TLC also featured plenary events, including a lunchtime roundtable on "Strategies for Teaching Challenging Issues" and the Pi Sigma Alpha Keynote Address, entitled "Helping Students Make Sense of a Changing Political World," delivered by Professor Jane Y. Junn of the University of Southern California. The meeting concluded on Sunday morning with a plenary session in which the attendees discussed "Where Do We Go from Here?" and offered concrete suggestions on next steps for enhancing teaching and learning throughout the discipline and within their own academic communities.

As was the case at the 2010 conference, the 2011 TLC featured live remote participation technology. Through the use of remote participation, the three plenary sessions were broadcast live via the Internet, allowing those who were unable to attend the meeting to join discussion virtually. This technology was made available by Professor Derrick Cogburn and his lab, COTELCO (Syracuse University and American University). The sessions are currently available at http://www.apsanet.org/content_69203.cfm.

APSA would like to thank the following individuals who served on the 2011 TLC Programming Committee and as track moderators:

- Mitchell Brown (chair), Auburn University (Teaching Research Methods)

- Derrick Cogburn, American University (Integrating Technology)

- Jeffrey S. Lantis, College of Wooster (Internationalizing the Curriculum II)

- Erin Richards, Cascadia Community College (Core Curriculum/General Education)

- Stephen Salkever, Bryn Mawr College (Teaching Theory and Political Theories)

- Deborah Ward, Rutgers University (Internationalizing the Curriculum I)

The following seven individuals also served as 2011 track moderators: Victor Asal, SUNY University of Albany (Simulations and Role Play I); Elizabeth Bennion, Indiana University South Bend (Civic Engagement II); Boris Ricks, University of California, Northridge (Diversity, Inclusiveness, and Equality); Ronald Shaiko, Dartmouth College (Civic Engagement I); Daniel E. Smith, Northwest Missouri State University (Simulations and Role Play I); John Ishiyama, University of North Texas (Graduate Education and
Professional Development); and Candace C. Young, Truman State University (Program Assessment).

\section{The 2012 APSA Teaching and Learning Conference}

The 2012 TLC will be held in Washington, DC, February 17-19, 2012, at the Grand Hyatt Washington. For more information on the call for proposals and registration, please visit http://www. apsanet.org/teachingconference.

\section{TLC Track Summaries}

The following TLC track summaries were written by 2011 TLC track participants and detail the key themes that emerged in each track. We hope that you find the information on and insights into teaching political science to be useful.

Kimberly A. Mealy, Director of Education, Professional Development, and Diversity Programs

\section{TRACK: CIVIC ENGAGEMENT I: EXPERIENTIAL} LEARNING/LEARNING COMMUNITIES

\section{S. Suzan J. Harkness, University of the District of Columbia \\ Michael Kuchinsky, Gardner Webb University \\ Christine Pappas, East Central University}

In 2004, 40 political scientists gathered in Washington, DC, to inaugurate the APSA Teaching and Learning Conference (TLC), which aimed to explore how we teach and how students learn best within the discipline. A common theme linking the activebased curriculum to political science over the past eight years has been the theory of experiential education. Over time, the vibrant conversation within this track has included community-based learning, service learning, civic engagement, community-based research, simulations, case studies, problem-based learning, and internships. The discourse has also shifted away from asking what civic engagement is and how we can integrate it into the curriculum toward questions such as:

- How do we assess and document learning?

- What is the long-term impact of civic engagement?

- What are the affordances to all participants?

- What constitutes success?

- What is more important, political engagement or civic engagement?

- What models can measure efficacy?

- Can we develop systematic standards?

- Is there a bias within the framework of some experiential education that favors more affluent students?

- Do traditional students', nontraditional students', and faculty's definitions of what constitutes political and civic engagement fall within the same realm of activities? 
The exchange of ideas within this track has matured as the discipline has developed best practices while documenting effectiveness.

This year in Albuquerque, 30 participants gathered to continue the conversation of civic engagement in track I. The majority of the track participants were first-time TLC participants, although some had attended more than one TLC, and one participant had attended six. The panel also had numerous international colleagues representing the United Kingdom, Ireland, and the Middle East. The track theme proposed to assess and evaluate active learning techniques that engaged students in their local and global communities by investigating the impact of these techniques on civic participation, class participation, political knowledge, and student learning. We talked in-depth about efficacy and explored the notion of how we define and determine success. Similar to the discussion that occurred in 2006, we agreed that planning was imperative in order to achieve the intended learning outcomes. In 2006, the panel called this approach the ${ }_{3} \mathrm{P}$ model (planning, planning, and more planning). As participants did in 2007, we grappled with how best to assess outcomes and the overall impact of students' experiences. Do we know if these activities have a longterm impact, especially as it pertains to efficacy? Several of the papers discussed the immediate benefits, social capital, and affordances of a civic engagement curriculum, which may be organized around four constituents: students, colleges and universities, the community, and the agent or organization receiving the student participation.

\section{What We Discussed}

Although many professors know experiential education to be a successful methodology, Mary McHugh ("Why Do We Do Civic Engagement? A Study of How and Why College Professors Use Experiential Learning in Their Classrooms") discussed the reasons why certain professors use experiential learning in their classrooms and why others do not. One hurdle to experiential learning that emerged in several of the papers was the difficulty in demonstrating results in teaching course objectives, civic engagement, and social capital. It may be that the most important outcomes, such as internal efficacy (Shea Robison and Mark K. McBeth, "I Think I Can, I Think I Can: Using Group Project-Based 101 Course Designs to Enhance Internal Efficacy") or emotions (Christine Pappas, "The Effects of Service Learning on Internal Efficacy and Emotions"), are hard to see. For example, Dr. Pappas examined students' emotional reactions to service-learning projects and produced many important observations. The discussion among participants explored the role of emotion and questioned whether emotion imparts strongly encoded learning. S. Suzan J. Harkness' paper ("Beyond Service to Learning: Best Practices and Affordances of Experiential Learning") also conveyed evidence that sustained and repeated civic engagement correlated with increases in efficacy and plans for future engagement.

Projects described experiential learning that ranged from limited six-hour internships in local government (Jennifer Jackman, "Mini-Internships, Public Administration and Civic Engagement") and classroom-based case studies (John Craig, "Using Scenarios for Learning in Political Science") to broad multiyear projects (James Simeone, "Assessing the Quality of Citizenship: Do Project Pedagogies Make a Difference?"; Maura Adshead, Andrea Nicole Deverell, and Eídín Ní Shé, "Fostering Inclusivity in Service Learning Initiatives through Emancipatory Action
Research"). Jackman described outcomes from a mini-internship model. This study recognized that the trial balloon internship provides outcomes that may lead students into longer-term experiential engagement. Moreover, the study documented that a six-hour shadowing experience impacted students' understanding of municipal complexity and afforded students a greater appreciation of public work. Simeone's small study discussed the importance of networking and social capital and how they dovetail with recently developed models to explain how the notion of new citizenship works. Adshead, Deverell, and Shé presented a very novel approach to civic engagement in which students worked on real-world problems. The project involved students in an effort to catalog the experiences of the Irish Travelers and people with the experience of the asylum process with respect to public services and discrimination. The project was creative, highly involved, and included action research. The decidedly successful outcome yielded numerous affordances beyond meaningful relationships that benefited the community and groups associated with the respective parties involved.

Experiential learning through extended internships and poll working was also discussed. Robbin E. Smith ("Civic Engagement: A Comparison of Community College and University Students") examined the outcomes of college students engaged in poll working and found that this experience produced a greater likelihood that students may maintain civic engagement in other areas of their lives. In analyzing the 2010 data, it was surmised that the students showed a marked willingness to engage in certain future activities. Jeffrey Sosland and Diane Lowenthal ("The Forgotten Educator: Experiential Learning's Internship Supervisor") shifted the focus to discuss the important role that the intern supervisor plays in students' experiential learning. Their study found that internship supervisors take their role seriously and feel that they play a dynamic and focal educative role in student learning.

Michael K. McDonald's innovative piece ("Out of the Classroom and into the Field: Helping Students Integrate Their Classroom Learning, Experiential Learning, and Professional Development") was an excellent capstone to the exploration of experiential learning, because it challenged professors to integrate and collaborate across disciplines and experiences both within and outside of the curriculum. Just as we try to help students understand why English composition or logic are important building blocks for the study of political science, we need to help students scaffold their study abroad, service learning, internship, and research experiences as a continuum of traditional courses and curriculum. Another point that became clear through our discussion was how a student's gender, class, or sexual orientation may mediate his or her response to experiential learning.

\section{Lessons Learned and Conclusions}

There were numerous takeaways from this panel that we would like to note:

- Reflection is critical to the experiential learning process and helps students clarify meaning.

- The unscripted and sometimes unpleasant experiences that may accompany out-of-the-classroom experiential learning may enhance the learning moment and provide value to augment the construction of knowledge. Real life is not always neat and tidy. 
- Integration of experiential education across the institutionour departments, colleges, and universities-is important.

- We need to dig deeper into the complex experiences in which students are involved.

- We must recognize the dialectic between the construction of knowledge and the development of efficacy.

- The developmental journey is important, and its effects are likely to be long-term and not always easy to evaluate or measure at the end of the semester.

- As political scientists, we need to be revising what we are talking about and how we are doing it, as one shoe does not fit all feet.

- Gender and different populations may benefit more or less from experiential education.

- The role of the community partner and its link to the university is very important in the student learning process.

- We need to better understand the differences (as well as overlaps) among service learning, civic engagement, and learning for political engagement.

- The National Society for Experiential Education (NSEE) offers "Eight Principles of Good Practice for All Experiential Learning Activities" that are significant in sharpening the experiential learning process and outcomes.

\section{TRACK SUMMARY: CIVIC ENGAGEMENT II: POLITICAL BEHAVIOR EFFECTS}

\section{Elizabeth A. Bennion, Indiana University South Bend Renée Bukovchik Van Vechten, University of Redlands}

This year's participants in the Civic Engagement II track agreed with last year's participants that civic engagement is both a means and an end. Active learning through community or political engagement can provide students with a deeper understanding of political science concepts while also helping them develop the skills they need to become engaged citizens. Participants in this year's track focused on how to assess the knowledge, skills, and dispositions that students develop through coursework, internships, and extracurricular programs.

Track moderator Elizabeth Bennion provided a toolkit ("Assessing Civic Education and Engagement Activities: A Toolkit") for assessing civic engagement activities, covering a full range of quantitative, qualitative, and mixed-methods approaches from participant counts to fully-randomized, multicampus field experiments. Bennion presented a summary of assessment methods used in civic education and engagement scholarship in the discipline and discussed the need for more teacher-scholars to clearly define their learning objectives to allow them to operationalize and measure learning outcomes. She stressed the importance of using both pretests and posttests to ensure that high levels of civic knowledge or engagement are not preexisting conditions and recommended both indirect and direct measures of student learning outcomes. For example, self-reports and surveys should be supplemented with tests of civic and political knowledge, writing assignments, or journals and evaluated using a rubric. Bennion also promoted the use of comparison or control groups to ensure that observed changes are actually the result of the program being evaluated. Finally, she highlighted the need to study behavior directly, whenever possible, and the need to conduct more longitudinal studies to test the long-term effects of civic engagement pedagogy.

While track members noted that instructors should not assume that a student's long-term civic attitudes and behavior will change dramatically after a single civic education experience, participants were encouraged by the measurable changes they observed in their research and teaching.

Several track participants presented their own research. One set of papers explored how civic skills are tested and developed through online social networking activities (Jenni Fitzgerald and Jacqueline A. Kelo, "Civic Participation and the Facebook Generation"; Renee Bukovchik Van Vechten and Anita Chadha, "How Students Talk to Each Other: Findings from an Academic Social Networking Project"). An assessment of how students interacted with each other through discussion boards on an academic website showed that online communities can function as a training ground for active social and political involvement. Helping each other develop informed perspectives by deliberating civilly was an important way that students practiced and learned the skills that form the basis for civic engagement.

From rural to urban settings, college courses incorporating public affairs internships or problem-solving activities can also provide students with opportunities to participate politically, improve their skills, and expand their notion of democratic citizenship. For instance, requiring students to take on a local issue, such as advocating for a stop sign at a busy intersection, can yield similar learning outcomes as those gained from interning in a Washington, DC, political office. According to two studies presented in the track, students' political knowledge, facility with policymaking procedures, and political efficacy appear to increase through hands-on experiences (Jeff Dense, "Civic Engagement in the Rural University"; Claire Haeg and Matthew Lindstrom, "Getting Potomac Fever: Increasing Civic Engagement through Internship Learning Communities"). Additionally, the subject matter need not be limited to the United States: one longitudinal research project demonstrated how an extended Model UN project that brings undergraduates studying international relations together with high school students can have lasting effects on individual attitudes about foreign affairs, knowledge, and levels of political efficacy (Alison Rios Millett McCartney, "What Happens after Graduation? An Evaluation of the Impacts of Civic Engagement Courses on Post-College Practices").

Efforts to teach students about civic affairs and provide experiential learning can be "brought together under one roof" by coordinating a university-wide program designed to spark wider interest in civic affairs that can also double as a resource center for local community and government groups. This kind of institutional commitment to promoting civic and political engagement can encourage interdisciplinary ventures that lead to similar positive outcomes among participants, including increased political awareness and knowledge and differences in political affect, as another presenter showed (Adam H. Hoffman, "Civic Engagement Institutes at Universities: Reaching beyond Political Science Majors"). However, all of these studies-whether about individual courses, internships, or a university institute-also reminded participants of the inherent limitations of assessing civic education and the incremental, diffuse, or qualitative gains that this education can produce, as well as the challenges presented by small $n s$ and the need to locate effective comparison or control groups. 